\title{
Novel Cell- and Tissue-Based Assays for Detecting Misfolded and Aggregated Protein Accumulation Within Aggresomes and Inclusion Bodies
}

\author{
Dee Shen · Jack Coleman $\cdot$ Eric Chan $\cdot$ \\ Thomas P. Nicholson · Lijun Dai · Paul W. Sheppard • \\ Wayne F. Patton
}

Published online: 5 December 2010

(C) The Author(s) 2010. This article is published with open access at Springerlink.com

\begin{abstract}
Aggresomes and related inclusion bodies appear to serve as storage depots for misfolded and aggregated proteins within cells, which can potentially be degraded by the autophagy pathway. A homogenous fluorescence-based assay was devised to detect aggregated proteins inside aggresomes and inclusion bodies within an authentic cellular context. The assay employs a novel red fluorescent molecular rotor dye, which is essentially nonfluorescent until it binds to structural features associated with the aggregated protein cargo. Aggresomes and related structures were generated within cultured cells using various potent, cell permeable, proteasome inhibitors: MG-132, lactacystin, epoxomicin and bortezomib, and then selectively detected with the fluorescent probe. Employing the probe in combination with various fluorescein-labeled primary antibodies facilitated co-localization of key components of the autophagy system (ubiquitin, p62, and LC3) with aggregated protein cargo by fluorescence microscopy. Furthermore, cytoplasmic aggregates were highlighted in SK-N-SH human neuroblastoma cells incubated with exogenously supplied amyloid beta peptide 1-42. SMER28, a small molecule modulator of autophagy acting via an mTOR-independent mechanism, prevented the accumulation of amyloid beta peptide within these cells. The described assay allows assessment of the effects of protein aggregation directly in cells, without resorting to the use of non-physiological protein mutations or genetically engineered cell lines. With minor modification, the assay was also adapted to the analysis of frozen or
\end{abstract}

D. Shen · J. Coleman - E. Chan - T. P. Nicholson - L. Dai ·

P. W. Sheppard - W. F. Patton ( $\square)$

Enzo Life Sciences, 10 Executive Blvd, Farmingdale,

NY 11735, USA

e-mail:wpatton@enzolifesciences.com formalin-fixed, paraffin-embedded tissue sections, with demonstration of co-localization of aggregated cargo with $\beta$-amyloid and tau proteins in brain tissue sections from Alzheimer's disease patients.

Keywords Aggresome - Inclusion bodies · Proteasome inhibitor · Ubiquitin-proteasome system · Misfolded proteins · p62 protein - LC3 - Autophagy · Alzheimer's disease $\cdot$ Protein homeostasis $\cdot$ Proteostasis

$\begin{array}{ll}\text { Abbreviations } \\ \text { FBS } & \text { Fetal bovine serum } \\ \text { EBSS } & \text { Earle's balanced salt solution } \\ \text { PBS } & \text { Phosphate buffered saline } \\ \text { GFP } & \text { Green fluorescent protein } \\ \text { LC3 } & \text { Microtubule associated proteins 1A/1B } \\ & \text { light chain 3 } \\ \text { DMSO } & \text { Dimethyl sulfoxide } \\ \text { UPS } & \text { Ubiquitin-proteasome system } \\ \text { HSR } & \text { Heat shock response } \\ \text { UPR } & \text { Unfolded protein response } \\ \text { ThT } & \text { Thioflavin T }\end{array}$

\section{Introduction}

Eukaryotic cells avoid accumulating extracellularly and intracellularlly derived toxic protein aggregates using a variety of homeostatic mechanisms, including the suppression of their formation by the molecular chaperone pathway and the degradation of any misfolded proteins by the ubiquitin-proteasome system (UPS) [1]. However, once protein aggregates have formed, they tend to become 
refractory to proteasome-mediated proteolysis and begin to accumulate within various inclusion bodies. For example, aggregated proteins may be concentrated by microtubuledependent retrograde transport to perinuclear sites of aggregate deposition, referred to as aggresomes [2]. Typically, an aggresome forms in response to some cellular stress, such as hyperthermia, viral infection or exposure to reactive oxygen species. These inclusion bodies appear to provide a cytoprotective function by sequestering the toxic, aggregated proteins. Aggresomes and related inclusion bodies that form when the UPS machinery is overwhelmed with aggregated proteins, may serve as storage depots for cargo awaiting degradation by autophagy. Certain cellular inclusion bodies associated with human disease are thought to arise from an aggresomal response, including neurofibrillary tangles and amyloid plaques associated with neurons in Alzheimer's disease, Lewy bodies associated with neurons in Parkinson's disease, intranuclear and cytoplasmic inclusions associated with neurons in Huntington's disease, Mallory bodies associated with liver cells in alcoholic liver disease, and hyaline inclusion bodies associated with astrocytes in amyotrophic lateral sclerosis [3].

Aggresomes and related inclusion bodies can be monitored by a variety of analytical methods including transmission electron microscopy and the combination of polyacrylamide gel electrophoresis and western blotting, but these approaches are relatively low-throughput, timeconsuming, labor-intensive, and require much experience for accurate interpretation [1, 4]. Certain wild-type or mutant proteins fused with green fluorescent protein (GFP) can be transiently transfected into cultured cells in order to create a model system that produces inclusion bodies that may be analyzed by fluorescence microscopy [5, 6]. While certainly valuable for many investigations, this approach does not allow analysis of native protein and peptide aggregates within cells. Additionally, GFP is a relatively large tag, which could potentially influence aggregation kinetics [7].

We report upon a novel red fluorescent molecular rotor dye specifically devised to detect aggregated proteins and peptides within aggresomes and related inclusion bodies. The dye is essentially non-fluorescent in solution, but becomes brightly fluorescent upon binding to the tertiary structure of aggregated proteins. The assay has been validated using a range of conditions known to modulate the UPS machinery and has been optimized for co-localization studies with fluorescently labeled antibodies, highlighting interactions between aggregated protein and peptide cargo with post-translational modifications and pathway proteins implicated in aggresome formation and the autophagic process in general, such as ubiquitin, p62 and, LC3. The assay is compatible with flow cytometry, allowing, for the first time, easy quantitation of denatured protein cargo within cells. It is also suitable for highlighting neurofibrillary plaques, composed of $\beta$-amyloid and tau protein, in brain tissue thin sections from Alzheimer's disease patients.

\section{Materials and Methods}

Dyes and Reagents

ProteoStat $^{\circledR}$ Aggresome Detection Kit and anti-fade mounting medium were from Enzo Life Sciences, Inc. (Plymouth Meeting, PA). All components of ProteoStat ${ }^{\circledR}$ Aggresome Detection Kit were prepared according to the manufacturer's instructions. Thioflavin T, Nile Red, and 1,8-aminonaphthalene sulfonate (ANS) were from SigmaAldrich Company (St. Louis, MO). SYPRO ${ }^{\circledR}$ Orange dye was from Life Technologies (Carlsbad, CA). $1 \mathrm{mM}$ stock solutions of the dyes were prepared in DMSO.

Fluorescence Enhancement upon Binding to Aggregated Protein

Various fluorescent dyes were evaluated with respect to the increase in fluorescence response in the presence of aggregated protein relative to monomeric protein. Model proteins included lysozyme, IgG, pyruvate kinase, and trypsin (Sigma-Aldrich Company). Each protein was denatured by incubation at elevated temperature. The assay was performed using $5 \mu \mathrm{M}$ of protein, either native or aggregated, and a dye concentration of $5 \mu \mathrm{M}$. The protein and dye were incubated together for $15 \mathrm{~min}$ at room temperature. Fluorescence intensity values were collected on a BioTek Synergy Mx fluorescence microplate reader (Winooski, VT). Fluorescence values were measured with excitation and emission slit widths set to $9 \mathrm{~nm}$, and at a constant PMT voltage. Emission and excitation values were customized for each dye shown in Fig. 1. The fluorescent response of each dye in the presence of native and aggregated protein was determined as well as signal generated by free dye in buffer. The ratio of signal for aggregated protein versus monomeric protein was determined after subtracting the no protein blank value.

\section{Cell Culture}

Human cervical adenocarcinoma epithelial cell line HeLa and SK-N-SH neuroblastoma cell line were both obtained from American Type Culture Collection (ATCC, Manassas, VA). HeLa and SK-N-SH cells were routinely cultured in Eagle's Minimum Essential Medium (ATCC) with low glucose, supplemented with $10 \%$ fetal bovine serum (FBS) (ATCC) and $100 \mathrm{U} / \mathrm{ml}$ penicillin, $100 \mu \mathrm{g} / \mathrm{ml}$ streptomycin 
Fig. 1 Fluorescence signal enhancement of various fluorescent dyes in the presence of aggregated $\mathrm{IgG}$ protein relative to monomeric counterpart. The graphs show the fluorescence intensity increase obtained for aggregated protein relative to monomeric protein

\begin{tabular}{|r|c|c|}
\hline & Ex $(\mathrm{nm})$ & Em $(\mathrm{nm})$ \\
\hline Nile Red & 585 & 665 \\
\hline SYPRO $^{\circ}$ Orange & 492 & 610 \\
\hline 1,8 -ANS & 350 & 492 \\
\hline Thioflavin T $^{\circ}$ & 435 & 495 \\
\hline ProteoStat $^{`}$ & 500 & 600 \\
\hline
\end{tabular}

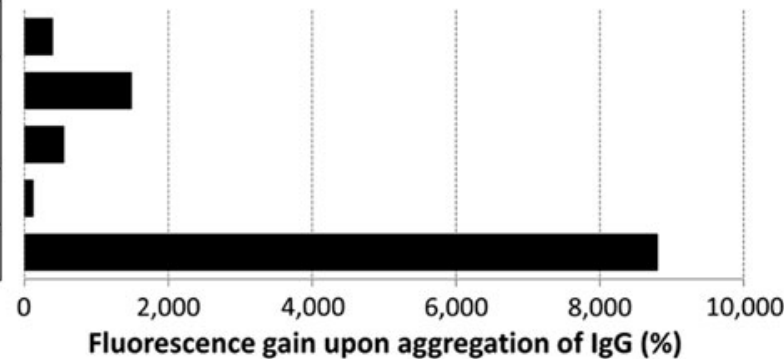

(Sigma-Aldrich). Human leukemic Jurkat cells were also obtained from ATCC. Jurkat cells were grown in suspension in RPMI medium supplemented with $10 \%$ (v/v) FBS, penicillin $(100 \mathrm{U} / \mathrm{ml})$, streptomycin $(100 \mu \mathrm{g} / \mathrm{ml})$, and glutamine $(200 \mathrm{mM})$. All cells were maintained in a saturated, humidified atmosphere at $37^{\circ} \mathrm{C}, 5 \% \mathrm{CO}_{2}$, and $95 \%$ air.

\section{Tissue Sections}

Post-mortem brain tissue (cerebellum) from patients with Alzheimer's disease and human adult normal brain tissue (cerebellum) were obtained from BioChain Institute, Inc (Hayward, CA). All tissue samples were received from certified tissue vendors who guarantee that they were collected with informed consent from the donors and their relatives, all samples were excised by licensed Medical Doctors, all normal and diseased tissues were determined by the donor's clinical reports and all collections were made with the relevant requirements for ethics committee/ IRB approvals. The frozen tissue sections were 5-10 $\mu \mathrm{m}$ in thickness, mounted on positively charged glass slides, and fixed with cold acetone by the manufacturer. The embedded tissue sections were fixed in formalin immediately after excision, and embedded in paraffin. Tissue sections were $\sim 5 \mu \mathrm{m}$ in thickness, and mounted on positively charged glass slides by the manufacturer.

\section{Small Molecule Compound and Peptide Treatment}

Proteasome inhibitors MG-132 (Enzo Life Sciences), lactacystin (Enzo Life Sciences), bortezomib (Velcade ${ }^{\circledR}$ ) (Selleck Chemicals LLC, Houston, TX), and epoxomicin (Enzo Life Sciences) were employed in the studies. The histone deacetylase 6 inhibitor, $N$-hydroxy-7-[5-(4-tertbutoxycarbonylaminophenyl)-3-isoxazolecarboxamido] heptamide (BML-281) was also obtained from Enzo Life Sciences. The small molecule compounds were reconstituted in DMSO at a concentration of $2 \mathrm{mM}$ for preparation of a stock solution and further diluted into culture medium to the final desired concentration prior to incubation with the cells for 6-18 h. Negative control cells were treated with a vehicle (DMSO, media or other solvent used to reconstitute or dilute the inducer or inhibitor) for an equal length of time under similar conditions.

Amyloid beta peptide 1-42 (21st Century Biochemicals, Marlboro, MA) was added to the culture medium and SK-N-SH cells were incubated overnight to induce aggresome formation. SMER28 (Enzo Life Sciences), an inducer of autophagy was employed to block this accumulation.

Autophagy was induced by several other treatment regimes as well. For amino acid starvation, cells were washed four or five times in Earle's Balanced Salt Solution (EBSS) and incubated in EBSS for $1 \mathrm{~h}$. Autophagy was also induced by various compounds (chloroquine, verapamil, rapamycin, $\mathrm{PP} 242$, lithium, trehalose, bafilomycin A1, hydroxychloroquine, loperamide, clonidine, and norclomipramine). These small molecule compounds were obtained from Sigma-Aldrich unless stated otherwise.

\section{Antibodies}

Antibodies were obtained from the following commercial sources: fluorescein-labeled p62 and LC3 reactive rabbit polyclonal antibodies and ubiquitin-reactive mouse monoclonal antibody (clone EX-9) were obtained from Enzo Life Sciences, Ltd. (Exeter, UK). These labeled conjugates were produced by direct labeling of antibodies raised to p62-derived, LC3-derived, and ubiquitin-derived peptides, respectively. A mouse monoclonal antibody reactive with human tau (clone tau-13) (Covance Inc, Emeryville, CA) is able to stain brain tissue early in Alzheimer's disease. It was used in conjunction with Alexa Fluor ${ }^{\circledR} 488$ dyelabeled goat anti-mouse secondary antibody from Life Technologies (Carlsbad, CA). Alexa Fluor ${ }^{\circledR} 488$ dyelabeled beta amyloid reactive mouse monoclonal antibody (clone 6E10), which is specifically reactive to amino acid residues $1-16$ of the human $\beta$-amyloid peptide, was obtained from Covance Inc.

\section{Cell-Based Assay}

Cells were grown on glass slides or polystyrene tissue culture dishes until $\sim 80 \%$ confluent. The cells were treated with various modulators or vehicle at various 
Table 1 Testing compounds as modulators of autophagy and proteasome pathways: Hela, Jurkat and SK-N-SH cells were treated with the highlighted compounds at the indicated concentrations and durations

\begin{tabular}{|c|c|c|c|c|c|c|}
\hline Treatment & Target & Effect & $\mu \mathrm{M}$ used & $\begin{array}{l}\text { Induction } \\
\text { time }(\mathrm{h})\end{array}$ & Cell line & $\begin{array}{l}\text { Aggresome } \\
\text { formation }\end{array}$ \\
\hline Starvation & Inhibits mammalian target of rapamycin (mTOR) & $\begin{array}{l}\text { Activates } \\
\text { autophagy }\end{array}$ & N/A & $1-4$ & $\begin{array}{r}\text { HeLa \& } \\
\text { Jurkat }\end{array}$ & No \\
\hline Rapamycin & Inhibits mammalian target of rapamycin (mTOR) & $\begin{array}{l}\text { Activates } \\
\text { autophagy }\end{array}$ & 0.2 & $6-18$ & $\begin{array}{r}\text { HeLa \& } \\
\text { Jurkat }\end{array}$ & No \\
\hline PP242 & ATP-competitive inhibitor of mTOR & $\begin{array}{l}\text { Activates } \\
\text { autophagy }\end{array}$ & 1 & 18 & Hela & No \\
\hline Lithium & $\begin{array}{l}\text { Inhibits IMPase and reduce inositol and } \mathrm{IP}_{3} \text { levels; } \\
\text { mTOR-independent }\end{array}$ & $\begin{array}{l}\text { Activates } \\
\text { autophagy }\end{array}$ & 10,000 & 18 & $\begin{array}{r}\text { HeLa \& } \\
\text { Jurkat }\end{array}$ & No \\
\hline Trehalose & Unknown, mTOR-independent & $\begin{array}{l}\text { Activates } \\
\text { autophagy }\end{array}$ & 50,000 & 6 & $\begin{array}{r}\text { HeLa \& } \\
\text { Jurkat }\end{array}$ & No \\
\hline Bafilomycin A1 & Inhibits vacuolar-ATPase & $\begin{array}{l}\text { Inhibits } \\
\text { autophagy }\end{array}$ & $6-9 \times 10^{-3}$ & 18 & $\begin{array}{r}\text { HeLa \& } \\
\text { Jurkat }\end{array}$ & Yes \\
\hline Chloroquine & Alkalinizes lysosomal pH & $\begin{array}{l}\text { Inhibits } \\
\text { autophagy }\end{array}$ & $10-50$ & 18 & $\begin{array}{r}\text { HeLa \& } \\
\text { Jurkat }\end{array}$ & Yes \\
\hline Tamoxifen & $\begin{array}{l}\text { Increases the intracellular level of ceramide and } \\
\text { abolishes the inhibitory effect of PI } 3 \mathrm{~K}\end{array}$ & $\begin{array}{l}\text { Activates } \\
\text { autophagy }\end{array}$ & $4-10$ & $6-18$ & $\begin{array}{r}\text { HeLa \& } \\
\text { Jurkat }\end{array}$ & Yes \\
\hline Verapamil & $\begin{array}{l}\mathrm{Ca}^{2+} \text { channel blocker; reducesintracytosolic } \mathrm{Ca}^{2+} \\
\text { levels; mTOR-independent }\end{array}$ & $\begin{array}{l}\text { Activates } \\
\text { autophagy }\end{array}$ & $40-100$ & 18 & $\begin{array}{c}\text { HeLa \& } \\
\text { Jurkat }\end{array}$ & Yes \\
\hline Hydroxychloroquine & Alkalinizes lysosomal pH & $\begin{array}{l}\text { Inhibits } \\
\text { autophagy }\end{array}$ & 10 & 18 & $\begin{array}{r}\text { HeLa \& } \\
\text { Jurkat }\end{array}$ & Yes \\
\hline Loperamide & $\begin{array}{l}\mathrm{Ca}^{2+} \text { channel blocker;reduces intra-cytosolic } \mathrm{Ca}^{2+} \\
\text { levels; mTOR-independent }\end{array}$ & $\begin{array}{l}\text { Activates } \\
\text { autophagy }\end{array}$ & 5 & 18 & $\mathrm{HeLa}$ & No \\
\hline Clonidine & $\begin{array}{l}\text { Imidazoline-1 receptor agonist; reduces cAMP } \\
\text { levels; mTOR-independent }\end{array}$ & $\begin{array}{l}\text { Activates } \\
\text { autophagy }\end{array}$ & 100 & 18 & HeLa & No \\
\hline MG-132 & Selective proteasome inhibitor & $\begin{array}{l}\text { Induce } \\
\text { aggresome }\end{array}$ & $2-5$ & 18 & $\begin{array}{r}\text { HeLa \& } \\
\text { Jurkat }\end{array}$ & Yes \\
\hline Epoxomicin & Selective proteasome inhibitor & $\begin{array}{l}\text { Induce } \\
\text { aggresome }\end{array}$ & 0.5 & 18 & HeLa & Yes \\
\hline Lactacystin & Selective proteasome inhibitor & $\begin{array}{l}\text { Induce } \\
\text { aggresome }\end{array}$ & 4 & & & Yes \\
\hline Velcade $^{\circledR}$ & Selective proteasome inhibitor & $\begin{array}{l}\text { Induce } \\
\text { aggresome }\end{array}$ & 0.5 & 18 & $\mathrm{HeLa}$ & Yes \\
\hline $\begin{array}{l}\text { Amyloid beta } \\
\text { peptide } 1-42\end{array}$ & Induce oxidative stress & $\begin{array}{l}\text { Induce } \\
\text { aggresome }\end{array}$ & 25 & 18 & SK-N-SH & Yes \\
\hline Norclomipramine & Alkalinizes lysosomal pH & $\begin{array}{l}\text { Inhibits } \\
\text { autophagy }\end{array}$ & $5-20$ & 18 & HeLa & Yes \\
\hline
\end{tabular}

Compounds that are listed as "Yes" under protein aggregation formation with ProteoStat ${ }^{\circledR}$ dye were determined either by a significant increase in fluorescence intensity in punctate cytoplasmic structures compared to control cells as observed by fluorescence microscopy or as possessing an APF value $>25$ determined as determined by flow cytometry

concentrations and time intervals, as detailed in Table 1. The cells were subsequently washed with PBS, and fixed in $4 \%$ formaldehyde in PBS for 30 min at room temperature, then permeabilized with $0.5 \%$ Triton X-100, 3 mM EDTA in PBS on ice, for $30 \mathrm{~min}$. The cells were washed with PBS, and then ProteoStat ${ }^{\circledR}$ dye (prepared according to kit instructions) was added. The samples were incubated for $30 \mathrm{~min}$ at room temperature, protected from light. The cells were washed with PBS, covered with glass coverslips and observed using a fluorescence microscope (Carl Zeiss MicroImaging $\mathrm{GmbH}$, Jena, Germany) equipped with a
Texas Red filter set. Images were acquired with a $63 \times$ objective lens (Carl Zeiss, Inc).

For antibody co-localization studies: cells were treated overnight with $5 \mu \mathrm{M}$ MG-132, then fixed and permeabilized using the above protocol. Then, the cells were incubated in PBS containing $3 \%$ bovine serum albumin (blocking buffer). Fluorescein-labeled p62, LC3, and ubiquitin (clone EX-9) reactive antibodies were diluted to a concentration of $1 \mu \mathrm{g} /$ $\mathrm{ml}$ in blocking buffer and incubated for $1 \mathrm{~h}$ at room temperature. Cells were then washed in PBS containing $0.1 \%$ Tween-20 for $15 \mathrm{~min}$. Next, the cells were stained with 
ProteoStat ${ }^{\circledR}$ dye (prepared according to kit instructions) for $30 \mathrm{~min}$ at room temperature and washed with PBS, covered with glass cover slip, sealed with nail polish, and observed by fluorescence microscopy using a Texas Red filter set for the ProteoStat ${ }^{\circledR}$ dye, and an FITC filter set for fluoresceinlabeled antibodies, respectively. All images were acquired with a $63 \times$ objective lens (Carl Zeiss, Inc).

\section{Staining of Tissue Sections}

Paraffin-embedded tissue sections were deparaffinized prior to staining. Briefly, the microscope slide-mounted specimen was immersed in a xylene substitute bath until the paraffin was solubilized. The deparaffinized specimens were then washed with a series of alcohol solutions of decreasing alcohol concentration, to remove xylene, before a final wash with water. Then, the tissue sections were fixed with $4 \%$ formaldehyde in PBS for $15 \mathrm{~min}$ at $37^{\circ} \mathrm{C}$. Following washing in deionized water, tissue sections were stained with either $1 \mu \mathrm{M}$ Thioflavin $\mathrm{T}$ in PBS or ProteoStat ${ }^{\circledR}$ dye $\left(2000 \times\right.$ in PBS from the ProteoStat ${ }^{\circledR}$ Aggresome Detection Kit) for $3 \mathrm{~min}$, rinsing in water and destained in $1 \%$ acetic acid for $20 \mathrm{~min}$. Finally, the tissue sections were washed thoroughly in water, dehydrated, covered with glass coverslips, mounted in anti-fade mounting medium, and observed using fluorescence microscope (Carl Zeiss, Inc) using an FITC filter set for Thioflavin $\mathrm{T}$ and a Texas Red filter set for ProteoStat ${ }^{\circledR}$ dye, respectively. All images were acquired with a $63 \times$ objective lens (Carl Zeiss, Inc).

For the antibody co-localization studies, tissue sections were stained with ProteoStat ${ }^{\circledR}$ dye as described above. The tissue sections were then blocked in PBS containing 3\% bovine serum albumin (blocking buffer). Tau-reactive monoclonal antibody (clone tau-13) and Alexa Fluor ${ }^{\circledR} 488$ labeled beta amyloid reactive monoclonal antibody (clone $6 \mathrm{E} 10)$ were diluted to a concentration of $2 \mu \mathrm{g} / \mathrm{ml}$ in blocking buffer and incubated for $1 \mathrm{~h}$ at room temperature. Tissues were then washed in PBS containing $0.1 \%$ Tween20 for $15 \mathrm{~min}$. For tissues incubated with Tau-13 antibody, the slides were subsequently incubated with Alexa Fluor ${ }^{\circledR}$ 488 goat anti-mouse secondary antibody for $30 \mathrm{~min}$ at room temperature. Finally, the tissue sections were washed with PBS, covered with glass coverslips, mounted in antifade mounting medium, and observed using a fluorescence microscope (Carl Zeiss, Inc) with a Texas Red filter set for ProteoStat ${ }^{\circledR}$ dye and FITC filter set for labeled antibodies, respectively. All images were acquired with a $63 \times$ objective lens (Carl Zeiss, Inc).

\section{Flow Cytometry}

HeLa cells or Jurkat cells were grown to log phase, and treated with $5 \mu \mathrm{M}$ MG-132 or with vehicle for $16 \mathrm{~h}$. At the end of the treatment, adherent cells were trypsinized; while Jurkat cells were simply collected by centrifugation $(400 \times g$ for $5 \mathrm{~min})$. Samples were resuspended at $1 \times 10^{6}$ to $2 \times 10^{6}$ cells $/ \mathrm{ml}$. For each group, triplicate samples were prepared. The cells were washed with PBS, fixed in $4 \%$ formaldehyde in PBS for 30 min and then permeabilized with $0.5 \%$ Triton X-100, 3 mM EDTA, $\mathrm{pH} 8$ on ice, for $30 \mathrm{~min}$. The cells were then washed, and resuspended in $500 \mu \mathrm{l}$ ProteoStat $^{\circledR}$ dye (prepared according to kit instructions). The samples were incubated for $30 \mathrm{~min}$ at room temperature, protected from light. Experiments were performed using a FACS Calibur benchtop flow cytometer (BD Biosciences, San Jose, CA) equipped with a blue $(488 \mathrm{~nm})$ laser. ProteoStat ${ }^{\circledR}$ dye fluorescence was measured in the FL3 channel. No washing was required prior to the flow cytometric analysis.

For the immunocytochemistry study, after fixing and permeabilizing the cells, the cells were blocked in PBS containing 3\% bovine serum albumin for $1 \mathrm{~h}$. Fluoresceinlabeled p62 antibody was diluted to a concentration of $2 \mu \mathrm{g} / \mathrm{ml}$ in blocking buffer and incubated with the cells for $1 \mathrm{~h}$ at room temperature. Cells were then washed in PBS containing $0.1 \%$ Tween-20 for $15 \mathrm{~min}$. Data were acquired by FACS Calibur benchtop flow cytometer (BD Biosciences, San Jose, CA) equipped with a blue (488 nm) laser, with the antibody signal measured in the FL1 channel.

\section{Statistical Analysis}

All of the experiments were performed at least three times. Flow cytometry data were analyzed by comparison of mean fluorescence, through calculation of a term we refer to as the Aggregation Propensity Factor (APF), as defined below.

$\mathrm{APF}=100 \times\left(\left(\mathrm{MFI}_{\text {treated }}-\mathrm{MFI}_{\text {control }}\right) / \mathrm{MFI}_{\text {treated }}\right)$, wherein $\mathrm{MFI}_{\text {treated }}$ and $\mathrm{MFI}_{\text {control }}$ are the mean fluorescence intensity values from control and treated samples.

This metric is based upon a similar approach that is commonly employed in the assessment of fluorescent signal between control and treated groups in multidrug resistance experiments, using a term referred to as Multidrug Resistance Activity Factor (MAF) [8]. APF is a unitless term measured as the difference between the amount of the ProteoStat ${ }^{\circledR}$ dye accumulated within cells in the presence and absence of a proteasome inhibitor or other inducer of aggresome or inclusion body formation or protein aggregation. The fluorescence measurement in the presence of the proteasome inhibitor constitutes the maximal potential fluorescence for the given cell population when aggregated protein cargo has been generated. This represents a standardization method, which eliminates unknown cell type-specific variables that might influence dye accumulation, such as cell size, shape, and volume, 
allowing the potential for intra- and inter-laboratory comparison of test results and APF values.

\section{Results}

Monitoring Aggregated Protein Cargo with ProteoStat ${ }^{\circledR}$ Dye

In order to better understand the nature and contribution of various autophagy pathway modulators to the specific targeting of protein cargo for degradation, a novel fluorescent dye was developed that facilitates detection and quantification of aggregated protein cargo within aggresomes and other inclusion bodies. A family of 130 molecular rotor dyes was synthesized, each member of which was designed to inherently decrease its non-radiative decay rate and increase fluorescence emission upon binding to the surface of aggregated proteins. The fluorescence properties of these molecular rotor dyes were measured in the unbound aqueous state and in the presence of a range of monomeric and denatured fibrillar proteins, including $\operatorname{IgG}$, lysozyme, pryuvate kinase, and trypsin. The lead dye from this screen is referred to as the ProteoStat ${ }^{\circledR}$ dye. The dye has an absorption maximum of $500 \mathrm{~nm}$ and emission maximum of $600 \mathrm{~nm}$. Relative to other dyes commonly employed for the analysis of aggregated protein, ProteoStat ${ }^{\circledR}$ dye provides a substantially higher fluorescence intensity enhancement in the presence of IgG aggregated protein relative to monomeric IgG protein (Fig. 1). Similar results were obtained for lysozyme, pryuvate kinase, and trypsin (data not shown).

The ability of the novel dye to detect aggregated proteins within fixed and permeabilized cells was next evaluated. MG-132, a relatively non-specific proteasome inhibitor, has also been shown to perturb protein homeostasis, inducing both the unfolded protein response (UPR) and the heat shock response (HSR) [9, 10]. MG-132 is known to accelerate the formation of perinuclear aggresomes as well as inclusion bodies within cells [6]. After treating cells with MG-132, ProteoStat ${ }^{\circledR}$ dye was found to readily highlight aggregated protein cargo accumulating within vacuolar cytoplasmic structures, as observed by fluorescence microscopy (Fig. 2). Examination of the distribution of the fluorescent dye within cells treated with MG-132, revealed a punctate pattern of cytoplasmic staining, as well as staining of certain inclusion bodies within or immediately adjacent to the nucleus itself. Multiple cytoplasmic inclusion bodies were readily discerned using the fluorescent dye. It should be noted that true aggresomes are characterized by a single large protein aggregate in cells that colocalizes with the centrosome in a microtubule-dependent fashion. The formation of the multiplicity of inclusion bodies we observed upon MG-132 treatment was not sensitive to the histone deacetylase 6 inhibitor, $N$-hydroxy-7-[5-(4-tertbutoxycarbonylaminophenyl)3-isoxazolecarboxamido]heptamide (BML-281) [11] or nocodazole (data not shown). This suggests that the generated inclusion bodies do not meet the strictest definition for aggresomes. The described probe appears to detect aggregated protein cargo within a variety of inclusion bodies, regardless of whether they are co-localized with the centrosome or formed in a microtubule-dependent manner.

The ability to detect aggresomes and related inclusion bodies was further demonstrated using various potent, cell permeable, and selective proteasome inhibitors: lactacystin, epoxomicin and bortezomib $\left(\right.$ Velcade $\left.^{\circledR}\right)$, as shown in Fig. 3. Previous studies have shown that bortezomibmediated proteasomal inhibition results in the accumulation of large quantities of ubiquitin-conjugated proteins organized into perinuclear structures termed "aggresomes" [12]. All of the tested proteasome inhibitors induced the accumulation of cytoplasmic inclusion bodies within the cells, as demonstrated with the ProteoStat ${ }^{\circledR}$ dye. Efforts to stain inclusion bodies in living cells were not met with success, however. Instead of discrete punctuate staining of aggregated cargo, a weak, diffuse cytoplasmic staining was observed that differed little between control cells and cells treated with a proteasome inhibitor. This could possibly be
Fig. 2 Protein aggregation detected by ProteoStat ${ }^{\circledR}$ dye as observed by fluorescence microscopy: Hela cells were mock-induced with $0.2 \%$ DMSO (a) or induced with $5 \mu \mathrm{M}$ MG-132 (b) for $16 \mathrm{~h}$ at $37^{\circ} \mathrm{C}$. After treatment, cells were incubated with ProteoStat ${ }^{\circledR}$ dye for $30 \mathrm{~min}$. Nuclei were counter-stained with Hoechst 33342 in the images

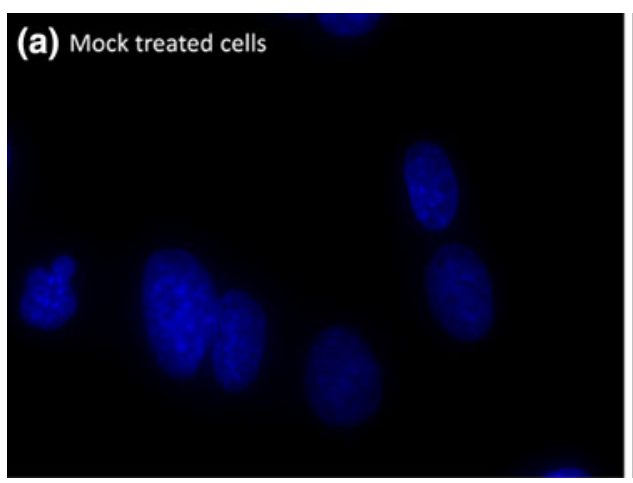

(b) 5 нM MG-132

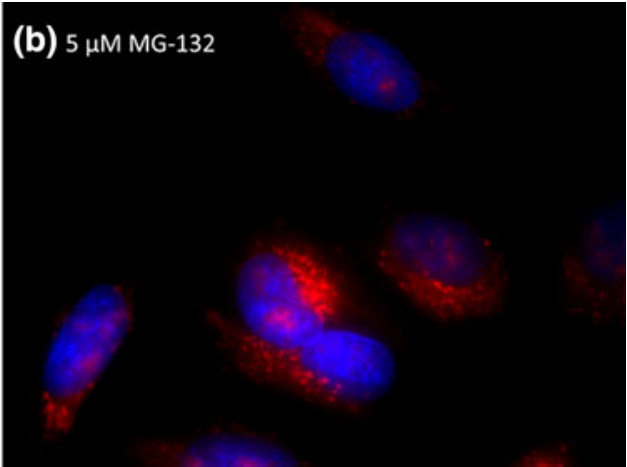


Fig. 3 Effect of various potent, cell permeable and selective proteasome inhibitors on protein aggregation in Hela cells, as observed by fluorescence microscopy a control, b $0.5 \mu \mathrm{M}$ epoxomicin, c $4 \mu \mathrm{M}$ lactacystin, and d $0.5 \mu \mathrm{M}$ Velcade ${ }^{\circledR}$ with $16 \mathrm{~h}$ incubation
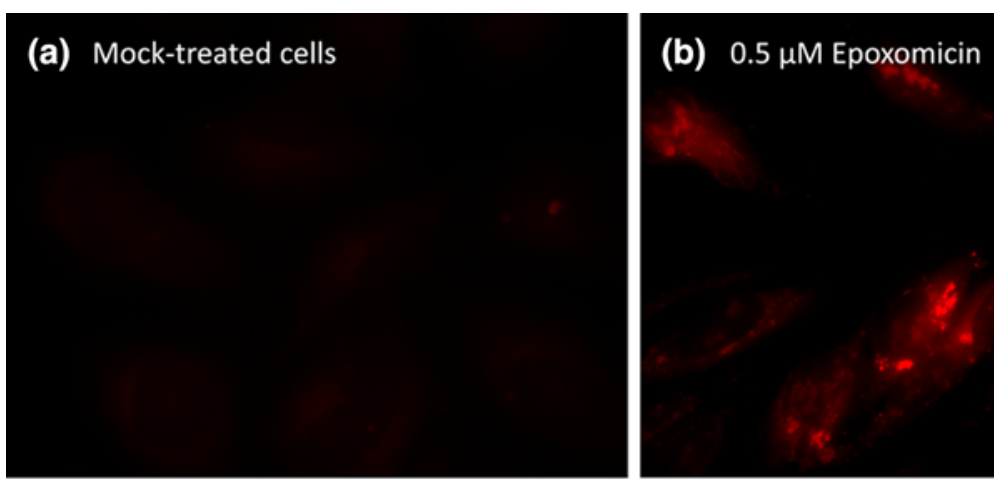

(c) $4 \mu \mathrm{M}$ Lactacystin

(d) $0.5 \mu \mathrm{M}$ Velcade ${ }^{\oplus}$
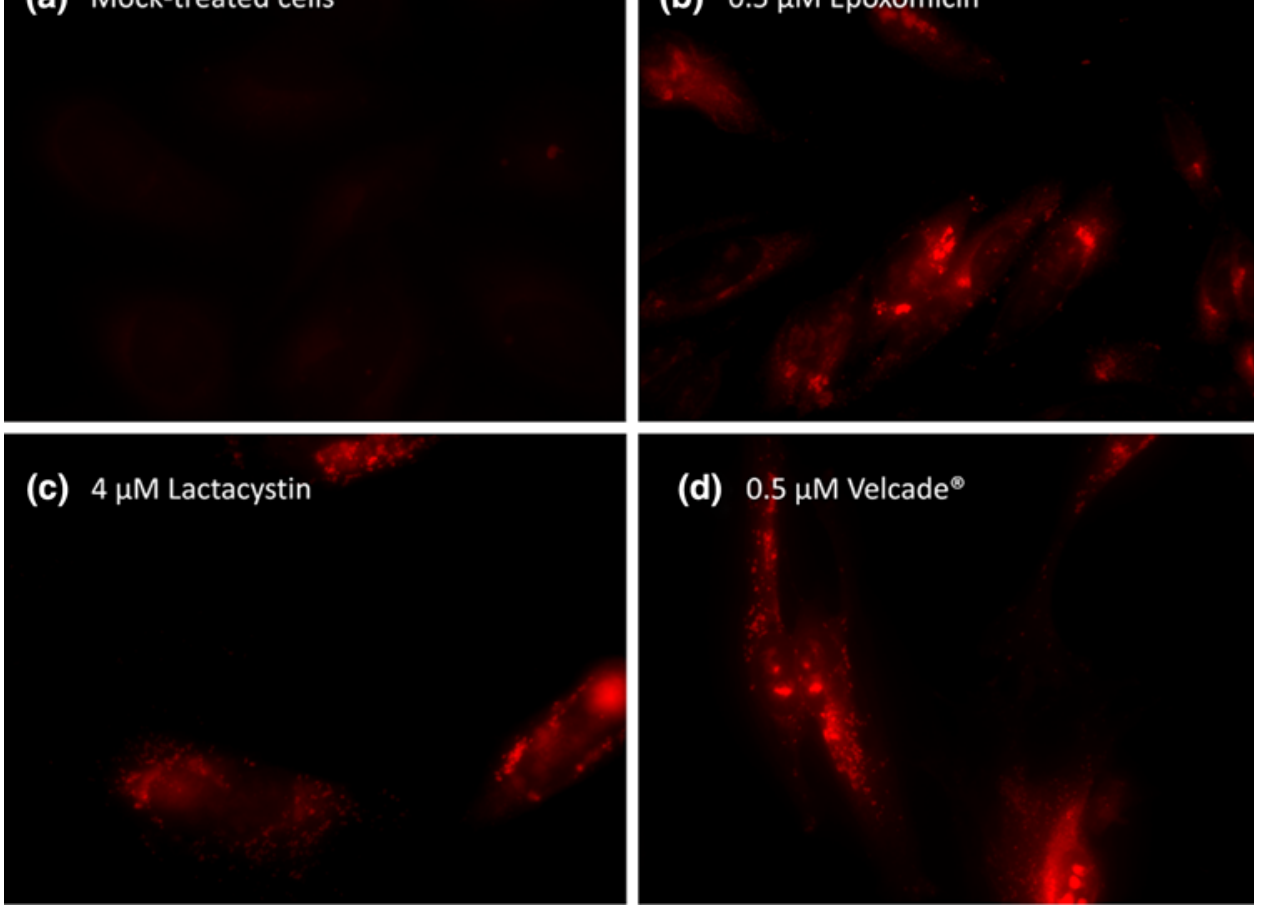

due to poor access of the dye to the contents of membranebound vacuolar structures within the cells.

A range of conditions, including treatment with various small molecule modulators of autophagy, were next evaluated using the cell-based protein aggregation assay (Table 1). Numerous small molecule compounds known to inhibit the autophagy pathway, leading to the accumulation of autophagosomes and autophagolysosomes, were also found to lead to protein cargo accumulating within vacuolar cytoplasmic structures, as observed by fluorescence microscopy. Aside from the proteasome inhibitors, Bafilomycin A, a potent and specific inhibitor of vacuolar $\mathrm{H}+$ ATPase, as well as certain cationic amphiphilic drugs (chloroquine, hydroxychloroquine, and norclomipramine), known to disrupt lysosomal function, also led to the accumulation of these cytoplasmic aggregates. Interestingly, two other cationic drugs, loperamide and clonidine, did not trigger an accumulation of aggregated proteins within the cells.

\section{Co-localization of Aggregated Protein \\ with Ubiquitinylation and Various Pathway Proteins Implicated in Autophagy}

Co-localization of fluorescently labeled ubiquitin antibody conjugate with ProteoStat ${ }^{\circledR}$ dye is shown in Fig. 4a, highlighting interactions between aggregated protein cargo and ubiquitinylation status. The ubiquitin signal is observed to be colocalized exclusively with the aggregated protein cargo, but it should be remembered that cells were fixed and permeabilized, which likely removed any free ubiquitin and ubiquitinylated substrates present in the cytosol. Figure $4 \mathrm{~b}$ demonstrates that a fluorescein-conjugated antibody directed toward p62 (a ubiquitin-binding scaffold protein that co-localizes with ubiquitinylated protein aggregates) also co-localizes with the ProteoStat ${ }^{\circledR}$ dye within cells treated with MG-132. Furthermore, co-localization between fluorescein-labeled antibodies reactive with LC3 (a ubiquitinlike autophagy cascade protein residing in the phagophore membrane) and aggregated protein cargo was demonstrated, as shown in Fig. 4c. The described co-localization studies demonstrate the capability of the ProteoStat ${ }^{\circledR}$ dye to be used to analyze the interactions between aggregated protein cargo, protein post-translational modifications, and various autophagy pathway proteins. The long wavelength red emission of the fluorescent probe is especially suitable for studies using green fluorescent dye conjugates, such as fluorescein, Alexa Fluor ${ }^{\circledR} 488$, Oregon Green ${ }^{\circledR} 488$, BODIPY $^{\circledR}-$ FL, HiLyte Fluor ${ }^{\mathrm{TM}} 488$, and DyLight ${ }^{\circledR} 488$.

\section{Cell Culture-Based Model Mimicking Elements of Alzheimer's Disease Pathology}

Next, we attempted to establish a cell culture-based assay mimicking the accumulation of $\beta$-amyloid, as observed in Alzheimer's disease. Figure 5b shows ProteoStat ${ }^{\circledR}$ dye is able to detect amyloid fibrils within an SK-N-SH human neuroblastoma cell line induced to form inclusion bodies by overnight incubation with exogenously added amyloid beta 1-42 peptide. Furthermore, SMER28, a small 


\section{(A)}
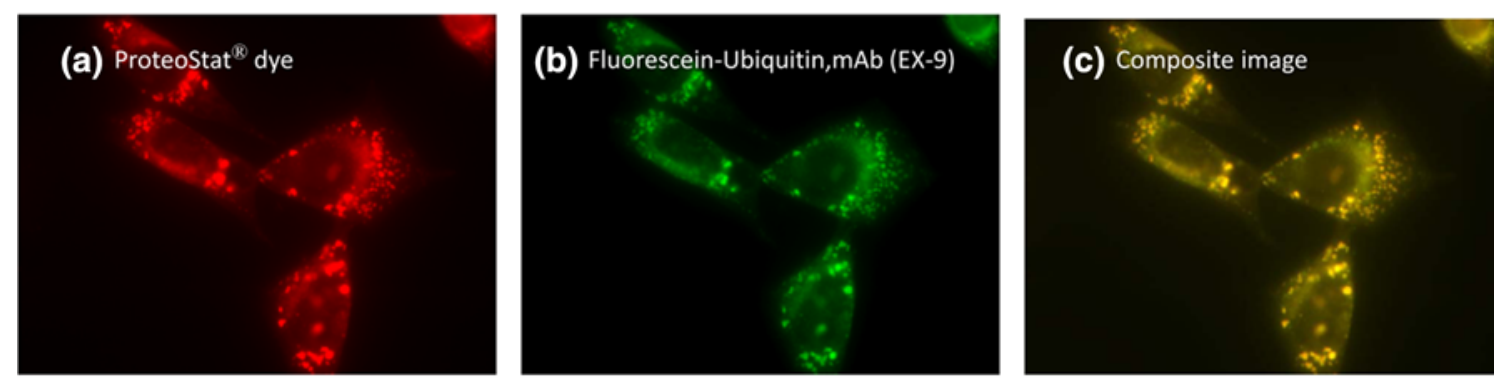

(B)
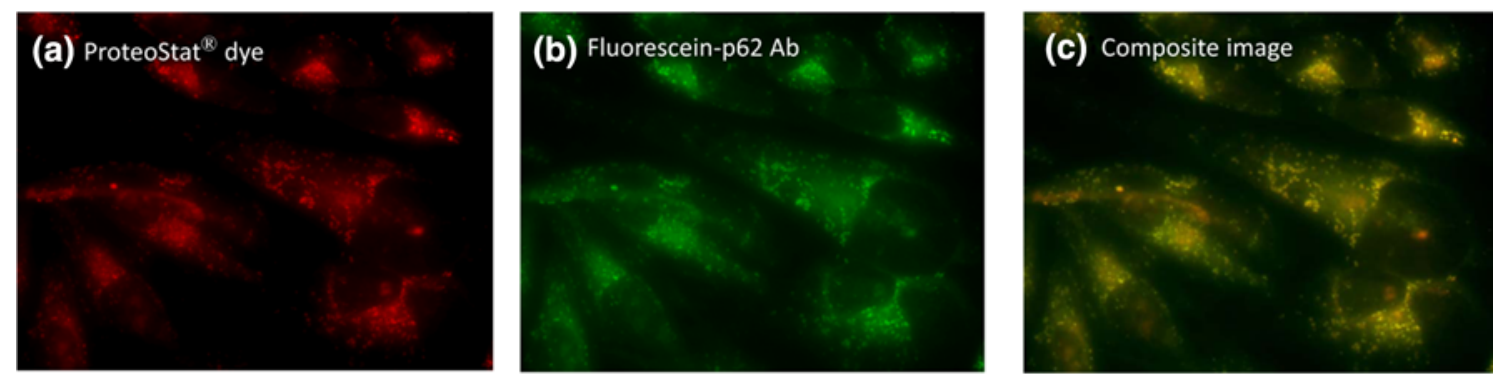

(C)
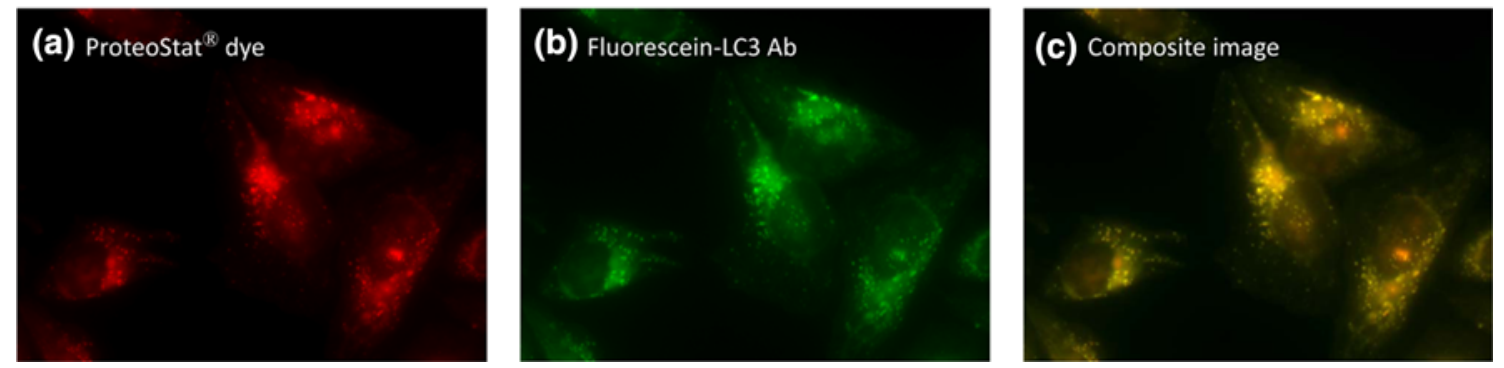

Fig. 4 Co-localization studies with fluorescently labeled antibodies, as observed by fluorescence microscopy. HeLa cells were treated for $12 \mathrm{~h}$ with $5 \mu \mathrm{M}$ MG-132. Panel $A$ Protein aggregation detected by ProteoStat ${ }^{\circledR}$ dye co-localizes with ubiquitin. a ProteoStat ${ }^{\circledR}$ dye stained, b cells treated with fluorescein-labeled ubiquitin-reactive antibody (clone EX-9) and c composite image. Panel B Protein aggregation detected by ProteoStat $^{\circledR}$ dye co-localizes with

molecule inducer of autophagy was evaluated with respect to its effect on $\beta$-amyloid peptide accumulation within the cells. SMER 28 has previously been shown to act via an mTOR-independent mechanism to increase autophagosome synthesis and enhance the clearance of model autophagy substrates, such as [A53T] $\alpha$-synuclein and mutant huntingtin fragments [13, 14]. It has also been demonstrated that SMER28 attenuates mutant huntingtinfragment toxicity in Drosophila models, suggesting therapeutic potential. As shown in Figs. 5c and d, SMER28 was able to substantially reduce accumulation of $\beta$-amyloid peptide in SK-N-SH human neuroblastoma cells, suggesting this assay could potentially enable screening of aggregation inhibitors relevant to neurodegenerative disease, in an authentic cellular context. fluorescein-labeled p62-reactive antibody. a ProteoStat ${ }^{\circledR}$ dye stained cells, b cells treated with fluorescein-labeled p62-reactive antibody, c composite image. Panel $C$ Protein aggregation detected by ProteoStat ${ }^{\circledR}$ dye co-localizes with LC3. a ProteoStat ${ }^{\circledR}$ dye stained, b cells treated with fluorescein-labeled LC3-reactive antibody and c composite image

Detecting Protein Aggregates in Post-Mortem Brain Tissue Sections from Patients with Alzheimer's Disease

Thioflavin $\mathrm{T}(\mathrm{ThT})$ is a widely employed histological probe for detecting the formation of amyloid fibrils in brain tissue [15]. However, this dye is not an ideal predictor of the degree of fibrillization because its fluorescence varies substantially depending upon the structure and morphology of the amyloid fibrils. We found that the dye generates fairly high background and weak fluorescent signal in brain tissue sections, as shown in Fig. 6a. Thus, optimized protocols for the detection of amyloid plaques in frozen and paraffin-embedded tissue sections of human brain were developed using the Proteostat ${ }^{\circledR}$ dye. Relative to ThT, this novel probe demonstrates significantly higher fluorescence emission intensity enhancement in 
Fig. 5 Treatment of SK-N-SH cells with amyloid beta peptide 1-42 induces aggregate formation, while SMER28 blocks this accumulation, as demonstrated by fluorescence microscopy. a Untreated cells, b $25 \mu \mathrm{M}$ amyloid beta peptide, c $25 \mu \mathrm{M}$ amyloid beta peptide with $5 \mu \mathrm{M}$ SMER 28, d $25 \mu \mathrm{M}$ amyloid beta peptide with $50 \mu \mathrm{M}$ SMER28
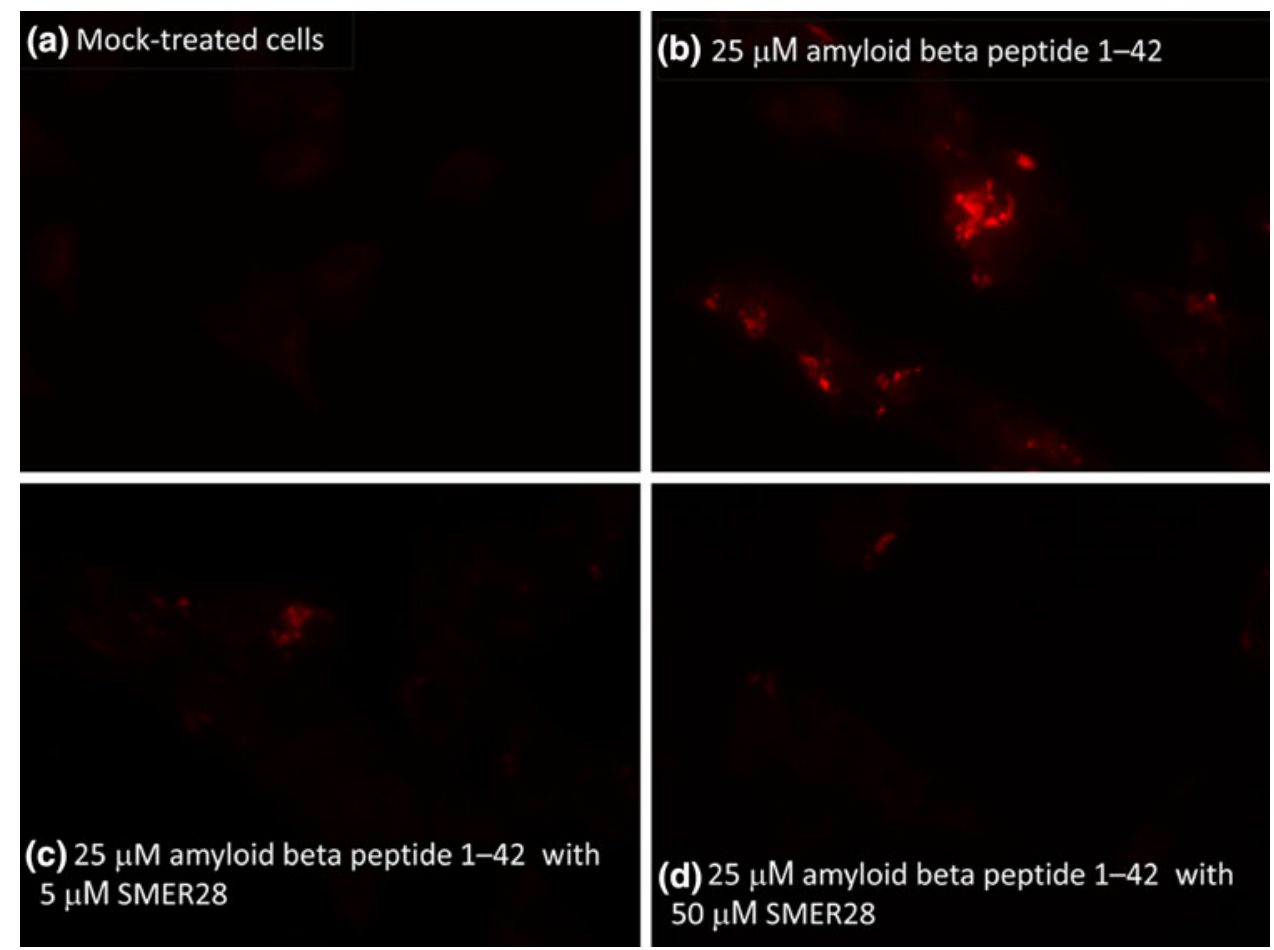

Fig. 6 Detection of amyloid plaques within paraffinembedded tissue sections of human brain tissue (cerebellum) from patients with Alzheimer's disease and human adult normal brain tissue (cerebellum) with a Thioflavin $\mathrm{T}$ dye,

b ProteoStat ${ }^{\circledR}$ dye, as observed by fluorescence microscopy

\section{(A)}

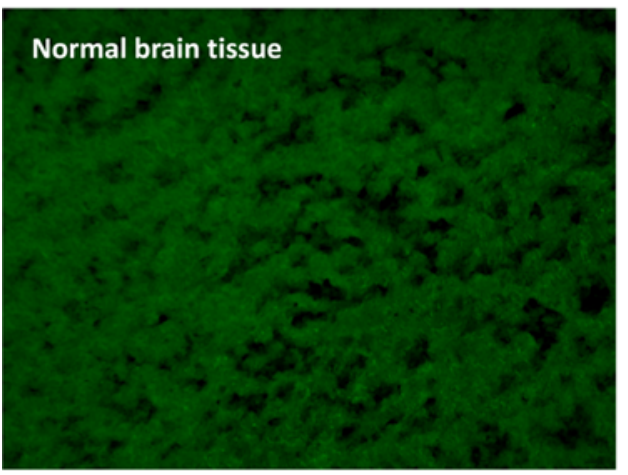

(B)

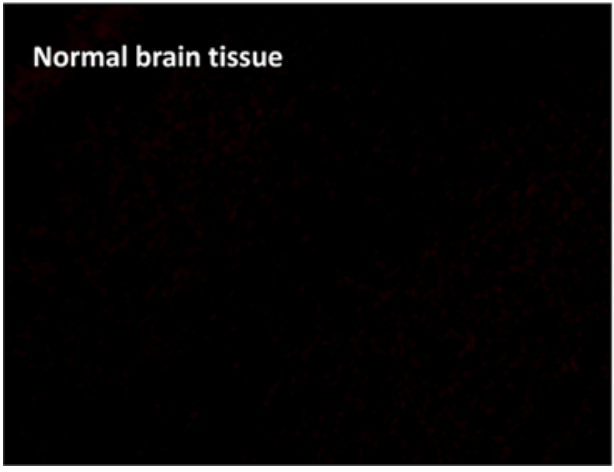

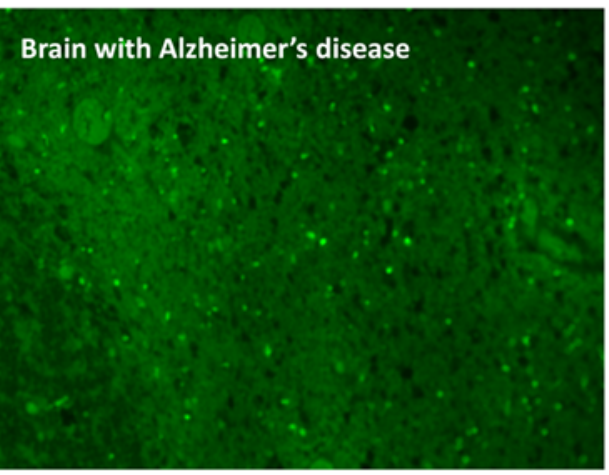

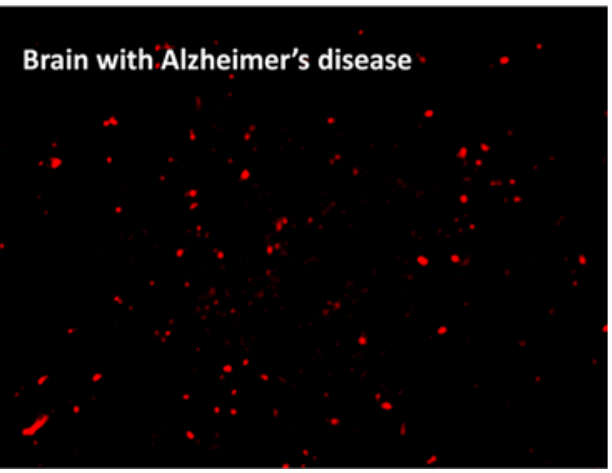

the presence of amyloid protein fibrils and low non-specific background (shown in Fig. 6b). In addition, use of antibodies directed against $\beta$-amyloid and tau protein, in conjunction with the ProteoStat ${ }^{\circledR}$ dye, confirm the selectivity of the probe for detection of amyloid plaques in post-mortem brain tissue of patients with Alzheimer's disease (Fig. 7a, b). 
(A)


(B)
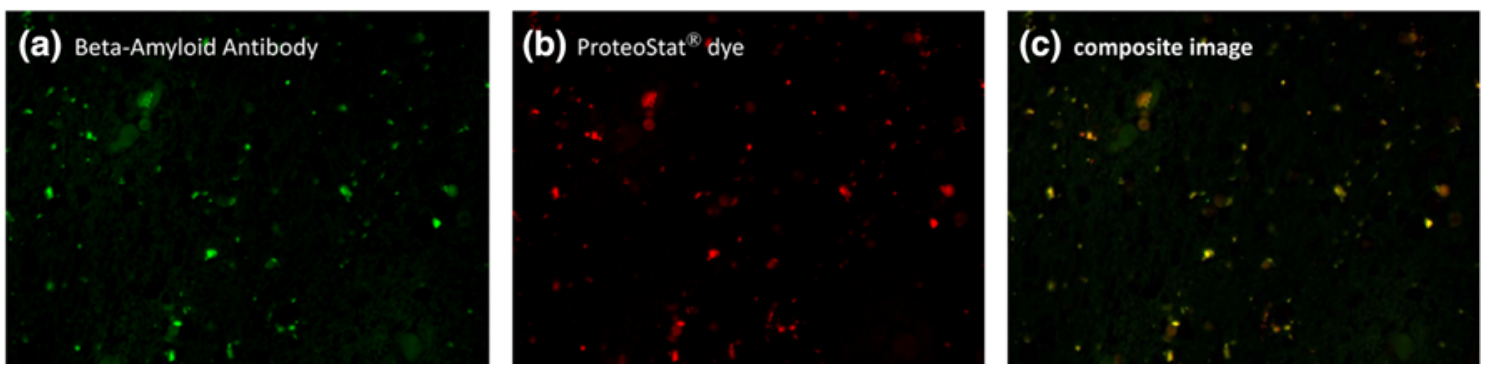

Fig. 7 Co-localization studies from amyloid plaques within paraffinembedded tissue sections of human brain tissue (cerebellum) from patients with Alzheimer's disease with fluorescently-labeled antibodies, as observed by fluorescence microscopy. Panel A ProteoStat ${ }^{\circledR}$ dye co-localizes with Tau protein. a Tau-reactive antibody (clone Tau-13) which recognizes human tau and specifically stains brain tissue early

\section{Utilizing Flow Cytometry to Quantify}

the Accumulation of Protein Aggregates Within Cells

A novel flow cytometry cell-based assay was next developed using the ProteoStat ${ }^{\circledR}$ dye. Figure 8a demonstrates typical results of flow cytometry-based analysis of cell populations using the ProteoStat ${ }^{\circledR}$ dye. Uninduced control and $5 \mu \mathrm{M}$ MG-132-treated Jurkat cells were employed in the investigation. After $16 \mathrm{~h}$ treatment, fixed and permeabilized cells were stained with the ProteoStat ${ }^{\circledR}$ dye and then analyzed without washing by flow cytometry. Results are presented using histogram overlay graphs. Control cells displayed minimal fluorescence staining with the dye. The ProteoStat ${ }^{\circledR}$ dye signal increased about three-fold in the MG-132 treated cells, readily demonstrating that MG-132 induced protein aggregate formation in Jurkat cells. An APF value of approximately 72, as defined in "Materials and Methods" section, demonstrates that the control and treated cell populations were readily distinguishable by flow cytometry. For comparison, routinely an MAF cut-off value of about 20-25 is employed in flow cytometry assays of multi-drug resistance [8]. Protein aggregate accumulation in the Jurkat cells was confirmed by flow cytometry analysis using fluorescein-conjugated p62-reactive antibody (Fig. 8b). Thus, the described assay allows, for the first time, easy quantification of aggresome accumulation in Alzheimer's disease, $\mathbf{b}$ ProteoStat ${ }^{\circledR}$ dye stained tissue, $\mathbf{c}$ composite image. Panel $B$ ProteoStat ${ }^{\circledR}$ dye co-localizes with beta amyloid. a beta amyloid reactive antibody (clone 6E10) which specifically binds $\beta$-amyloid aggregates, b ProteoStat $^{\circledR}$ dye stained tissue, c composite image

by flow cytometry. The advantage of the dye-based approach relative to the antibody one is that staining and analysis are much more rapid. Simultaneous staining with the fluorescein-conjugated antibody and the red fluorescent dye was also feasible (data not shown).

\section{Discussion}

Our overall objective was to develop an improved fluorescent probe for the analysis of aggregated protein cargo within cells and tissues. The benzothiazole dye, Thioflavin $\mathrm{T}(\mathrm{ThT})$, has routinely been employed for the determination of aggregated protein deposits, both ex vivo and in vitro. In the presence of amyloid fibrils, ThT displays a strong increase in fluorescence intensity, with excitation and emission maxima of roughly 440 and $490 \mathrm{~nm}$, respectively, depending on buffer composition. The intercalation of ThT molecules into grooves between solvent-exposed side chains within the characteristic crossed- $\beta$-sheet structure of the amyloid fibril appears to lead to the increased fluorescence signal [16]. ThT is a molecular rotor dye and it is thought that the dramatic increase in quantum yield upon binding to aggregated proteins arises from inhibition of the free rotation of its constituent aromatic rings. Conversely, in aqueous solution 
Fig. 8 Identifying protein aggregation by flow cytometry: Jurkat cells were mock-induced with $0.2 \%$ DMSO or induced with $5 \mu \mathrm{M}$ MG-132 for $16 \mathrm{~h}$ at $37^{\circ} \mathrm{C}$. After treatment, cells were fixed and incubated with a ProteoStat ${ }^{\circledR}$ dye, or b fluorescein-labeled p62reactive antibody. Then, the samples were analyzed by flow cytometry. Results are presented as histogram overlays. In MG-132 treated cells, ProteoStat ${ }^{\circledR}$ dye red fluorescence signal increases about 3 -fold (shown in panel $A$ ) while the fluorescein signal increases about 2.5-fold (shown in panel B) (a) Identifying Aggresomes by Flow Cytometry using ProteoStat ${ }^{\circledR}$ Dye

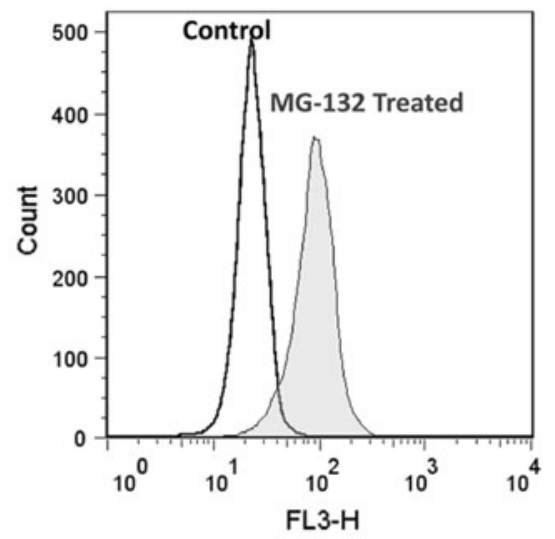

\begin{tabular}{|l|c|}
\hline Treatment & $\begin{array}{c}\text { Mean (FL3) } \\
\text { Signal }\end{array}$ \\
\hline Control & 25.1 \\
\hline Treated (5 $\mu$ M MG132) & 91.8 \\
\hline $\begin{array}{l}\text { Aggresome Propensity } \\
\text { Factor }\end{array}$ & $\mathbf{7 2}$ \\
\hline
\end{tabular}

(b) Identifying Aggresomes with Fluorescein-p62 Ab by flow cytometry

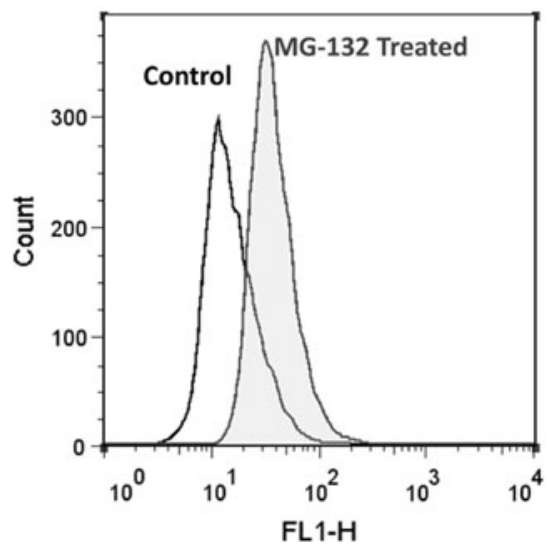

\begin{tabular}{|l|c|}
\hline Treatment & $\begin{array}{c}\text { Mean (FL1) } \\
\text { Signal }\end{array}$ \\
\hline Control & 17.8 \\
\hline Treated (5 $\mu$ M MG132) & 44.2 \\
\hline $\begin{array}{l}\text { Aggresome Propensity } \\
\text { Factor }\end{array}$ & 60 \\
\hline
\end{tabular}

when molecular rotation is not constrained, excited ThT molecules apparently undergo a torsional relaxation which effectively competes with the radiative transition, rendering the molecule essentially non-fluorescent.

The strong absorptive and fluorescent properties of certain phenolic aromatic small molecules, such as quercetin and curcumin, have been shown to significantly bias ThT-based fluorescence measurements [17]. For example, the presence of $10 \mathrm{nM}$ curcumin is sufficient to interfere substantially with fluorescence signal generation associated with ThT binding to fibrillar $\beta$-amyloid (1-42). This can be problematic when ThT-based fluorescence assays are employed for studies where the impact of polyphenolic compounds on protein fibrillation is being monitored, such as in small molecule compound screening projects designed to identify anti-amyloid drug candidates. Indeed, intrinsic tissue fluorescent properties of various cellular constituents, such as flavins, reduced $\mathrm{NAD}(\mathrm{P}) \mathrm{H}$, collagen, and elastin also substantially overlap with the absorption and fluorescence emission wavelengths of ThT [18]. Additionally, aldehyde fixatives are known to form covalent bonds between adjacent amine-containing groups through Schiff acid-base reactions to generate autofluorescent background with similar spectral properties to those of ThT [18].

A fluorescent derivative of Congo Red, (trans, trans)-1bromo-2,5-bis-(3-hydroxycarbonyl-4-hydroxy)styrylbenzene (BSB), has also been employed for the detection of amyloid deposits in tissue sections [19]. With an emission maximum of $520 \mathrm{~nm}$, this probe offers improved performance with respect to the avoidance of background associated with intrinsic and fixative-induced autofluorescence in cells and tissues. However, the probe's absorption maximum of $340 \mathrm{~nm}$ requires an ultraviolet laser source for optimal excitation, restricting its widespread adoption on various instrument platforms.

The ProteoStat ${ }^{\circledR}$ dye was developed to overcome the inherent limitations of commonly employed molecular probes for the assessment of protein aggregates in cells and tissues. Like ThT and BSB, the ProteoStat ${ }^{\circledR}$ dye is a molecular rotor that binds selectively to aggregated protein. The dye's red fluorescence emission maximum of $600 \mathrm{~nm}$ minimizes background problems associated with intrinsic or fixative-induced auto-fluorescence. Since 
detection of aggregated protein cargo with the ProteoStat ${ }^{\circledR}$ dye is based upon obtaining fluorescent signal at longer wavelengths than used for ThT and BSB dyes, it potentially enables the quantification of amyloid fibrils in the presence of colored and fluorescent compounds that interfere with fluorescence signal generated by these other dyes. Figure 6 highlights the substantial reduction in background noise afforded by the ProteoStat ${ }^{\circledR}$ dye relative to ThT.

The ProteoStat ${ }^{\circledR}$ dye's absorbance maximum of $500 \mathrm{~nm}$ enables its implementation on a wide variety of instrument platforms, including any flow cytometer equipped with a $488 \mathrm{~nm}$ argon ion laser. Relative to ThT and BSB, the ProteoStat $^{\circledR}$ dye's absorbance maximum is well aligned with the emission of a standard argon ion laser source. As described herein, we were able to detect aggregated protein cargo within aggresomes and related inclusion bodies effectively in both fixed and permeabilized cells by flow cytometry (Fig. 8). The APF value was calculated from the absolute fluorescence obtained in the absence and presence of MG-132, using the equation provided in "Materials and Methods" section. A readily measurable difference between control and MG-132 treated cells was clearly demonstrated, indicating that the described flow cytometry assay provides a reliable quantitative measure of aggregated protein cargo accumulation within cells. To our knowledge, we present the first dye-based flow cytometry approach to quantification of aggregated protein in aggresomes and related inclusion bodies residing within cells.

An alternative approach to detect aggregated protein cargo within cells relies upon genetically encoded live-cell fluorescent biosensors. Typically, an inclusion body-forming protein fused to green fluorescent protein (GFP) is overexpressed in a cell line in order to monitor the protein aggregation process [20,21]. The adoption of GFP technology to over-express fusions of aggregation-prone proteins has allowed study of the aggregation phenomenon in living cells. Although these genetically encoded aggregation sensors provide a means of identifying aggresomes and related inclusion bodies, none report directly on the levels and activities of endogenous proteins and peptides themselves. One potential limitation to the implementation of GFP fusion proteins in this context is the real possibility of steric hindrance at the $\mathrm{N}$ - or C-terminus of the aggregation-prone protein, interfering with the ordered self-association process. This is particularly of concern with respect to studies involving aggregation-prone peptides. For instance, GFP (238 amino acids) is roughly six times larger than $\beta$-amyloid peptides (39-43 amino acids), the principal components of amyloid plaques found in the brains of Alzheimer's disease patients. While the ProteoStat ${ }^{\circledR}$ dye can not currently be employed to stain living cells, it is suitable for staining fixed and permeabilized ones, allowing co-localization studies with antibodies to various other proteins of interest.
There is a growing body of evidence that neurodegenerative diseases, such as Alzheimer's disease, Parkinson's disease, and Huntington's disease encompass common cellular and molecular mechanisms involving protein aggregation and inclusion body formation [22]. The aggregates usually consist of fibers containing misfolded protein with a beta-sheet conformation, termed amyloid. Usually, these deposits contain ubiquitinylated protein conjugates, suggesting a failure in the clearance of proteins targeted for proteasomal degradation. The ubiquitin-proteasome system (UPS) is thought to be limited in its capacity to degrade aggregated proteins. Instead, their removal is believed to be primarily mediated by autophagy, a system by which cells sequester cytosolic cargo for delivery to lysosomes. The UPS and autophagy pathways were once considered separate systems but it now appears there is cross-talk and cooperation between them, with ubiquitin modification acting as a signalling molecule in both cases. The p62 protein (also called sequestosome 1 (SQSTM1)) is an ubiquitin-binding scaffold protein that co-localizes with ubiquitinylated protein aggregates in, for example, many neurodegenerative diseases and proteinopathies of the liver. In addition to its putative role in the targeting of ubiquitinylated cargo for proteasomal degradation, p62 binds both target-associated ubiquitin and LC3 (an ubiquitin-like autophagy cascade protein) conjugated to the phagophore membrane, thereby effectively serving as an autophagic receptor for ubiquitinylated targets [23]. Aggresomes, inclusion bodies that form when the ubiquitin-proteasome machinery is overwhelmed with aggregated proteins, may serve as storage depots for cargo awaiting degradation by autophagy. Using the ProteoStat ${ }^{\circledR}$ dye, we were able to confirm colocalization of aggregated protein cargo, ubiquitin, p62, and LC3.

Current methods for identifying potential fibrillization inhibitors are primarily based upon first screening compounds biochemically using purified protein (tau) or peptide ( $\beta$-amyloid), followed by testing in animals [24]. However, different biochemical assays have been found to generate different compound leads. In addition, since the biochemical assays are based upon using a single peptide or protein to measure self-association, no aggregation pathway modulators can be identified by the approach. Most compounds that inhibit $\beta$-amyloid or tau aggregation in these biochemical assays have subsequently failed to demonstrate effectiveness in animal studies. Methods based upon monitoring the aggregation state of a pure protein or peptide fail to recapitulate any cellular regulatory pathways that might influence protein aggregation state or accumulation. The described dye-based assay allowed assessment of the role of SMER28, an activator of autophagy, on the accumulation of $\beta$-amyloid within neuroblastoma cells, highlighting the potential utility of this 
basic approach to the identification of small molecule regulators that do not directly interfere with the aggregation of the target protein or peptide. The described approach could find application in the identification of activators of autophagy that might facilitate clearance of aggregated protein cargo from cells and tissues.

Open Access This article is distributed under the terms of the Creative Commons Attribution Noncommercial License which permits any noncommercial use, distribution, and reproduction in any medium, provided the original author(s) and source are credited.

\section{References}

1. Kopito, R. R. (2000). Aggresomes, inclusion bodies and protein aggregation. Trends in Cell Biology, 10, 524-530.

2. Amijee, H., Madine, J., Middleton, D. A., \& Doig, A. J. (2009). Inhibitors of protein aggregation and toxicity. Biochemical Society Transactions, 37(4), 692-696.

3. Dedeoglu, A., Kubilus, J. K., Jeitner, T. M., Matson, S. A., Bogdanov, M., Kowall, N. W., et al. (2002). Therapeutic effects of cystamine in a murine model of Huntington's disease. The Journal of Neuroscience, 22(20), 8942-8950.

4. Taylor, J. P., Tanaka, F., Robitschek, J., Sandoval, C. M., Taye, A., Markovic-Plese, S., et al. (2003). Aggresomes protect cells by enhancing the degradation of toxic polyglutamine-containing protein. Human Molecular Genetics, 12, 749-757.

5. Zaarur, N., Meriin, A. B., Gabai, V. L., \& Sherman, M. Y. (2008). Triggering aggresome formation. Dissecting aggresometargeting and aggregation signals in synphilin 1. Journal of Biological Chemistry, 283(41), 27575-27584.

6. Beaudoin, S., Goggin, K., Bissonnette, C., Grenier, C., \& Roucou, X. (2008). Aggresomes do not represent a general cellular response to protein misfolding in mammalian cells. BMC Cell Biology, 9, 59. doi:10.1186/1471-2121-9-59.

7. Saito, Y., Kishida, K., Takata, K., Takahashi, H., Shimada, T., Tanaka, K., et al. (2009). A green fluorescent protein fused to rice prolamin forms protein body-like structures in transgenic rice. Journal of Experimental Botany, 60(2), 615-627.

8. Hollo, Z., Homolya, L., Davis, C. W., \& Sarkadi, B. (1994). Calcein accumulation as a fluorometric functional assay of the multidrug transporter. Biochimica et Biophysica Acta, 1191(2), 384-388.

9. Mu, T. W., Ong, D. S., Wang, Y. J., Balch, W. E., Yates, J. R, 3rd, Segatori, L., et al. (2008). Proteostasis regulators and pharmacologic chaperones synergise to correct protein misfolding diseases. Cell, 134(5), 769-781.

10. Murakawa, Y., Sonoda, E., Barber, L. J., Zeng, W., Yokomori, K., Kimura, H., et al. (2007). Inhibitors of the proteasome suppress homologous DNA recombination in mammalian cells. Cancer Research, 67(18), 8536-8543.
11. Kawaguchi, Y., Kovacs, J. J., McLaurin, A., Vance, J. M., Ito, A., $\&$ Yao, T. P. (2003). The deacetylase HDAC6 regulates aggresome formation and cell viability in response to misfolded protein stress. Cell, 115, 727-738.

12. Nawrocki, S. T., Carew, J. S., Pino, M. S., Highshaw, R. A., Andtbacka, R. H., Dunner, K, Jr, et al. (2006). Aggresome disruption: a novel strategy to enhance bortezomib-induced apoptosis in pancreatic cancer cells. Cancer Research, 66, 3773-3781.

13. Sarkar, S., Perlstein, E. O., Imarisio, S., Pineau, S., Cordenier, A., Maglathlin, R. L., et al. (2007). Small molecules enhance autophagy and reduce toxicity in Huntington's disease models. Nature Chemical Biology, 3(6), 331-338.

14. Renna, M., Jimenez-Sanchez, M., Sarkar, S., \& Rubinsztein, D. C. (2010). Chemical inducers of autophagy that enhance the clearance of mutant proteins in neurodegenerative diseases. Journal of Biological Chemistry, 285(15), 11061-11067.

15. Westermark, G. T., Johnson, K. H., Westermark, P. (1999). Staining methods for identification of amyloid in tissue. Methods in Enzymology, 309, 3-25.

16. Biancalana, M., \& Koide, S. (2010). Molecular mechanism of Thioflavin-T binding to amyloid fibrils. Biochimica et Biophysica Acta, 1804(7), 1405-1412.

17. Hudson, S. A., Ecroyd, H., Kee, T. W., \& Carver, J. A. (2009). The Thioflavin $\mathrm{T}$ fluorescence assay for amyloid fibril detection can be biased by the presence of exogenous compounds. FEBS Journal, 276, 5960-5972.

18. Viegas, M. S., Martins, T. C., Seco, F., \& do Carmo, A. (2007). An improved and cost-effective methodology for the reduction of autofluorescence in direct immunofluorescence studies on formalin-fixed paraffin-embedded tissues. European Journal of Histochemistry, 51(1), 59-66.

19. Ando, Y., Haraoka, K., Terazaki, H., Tanoue, Y., Ishikawa, K., Katsuragi, S., et al. (2003). Novel tool for detecting amyloid deposits in systemic amyloidosis in vitro and in vivo. Laboratory Investigation, 83(12), 1751-1759.

20. Wang, Y. P., Biernat, J., Pickhardt, M., Mandelkow, E., \& Mandelkow, E. M. (2007). Stepwise proteolysis liberates tau fragments that nucleate the Alzheimer-like aggregation of fulllength tau in a neuronal cell model. Proceedings of the National Academy of Science, 104(24), 10252-10257.

21. Bennett, E. J., Bence, N. F., Jayakumar, R., \& Kopito, R. R. (2005). Global impairment of the ubiquitin-proteasome system by nuclear or cytoplasmic protein aggregates precedes inclusion body formation. Molecular Cell, 17(3), 351-365.

22. Ross C. A., Poirier M. A. (2004). Protein aggregation and neurodegenerative disease. Nature Medicine, S10-S17.

23. Bjørkøy, G., Lamark, T., Brech, A., Outzen, H., Perander, M., Overvatn, A., et al. (2005). p62/SQSTM1 forms protein aggregates degraded by autophagy and has a protective effect on huntingtin-induced cell death. Journal of Cell Biology, 171(4), 603-614.

24. Crowe, A., Huang, W., Ballatore, C., Johnson, R. L., Hogan, A. M., Huang, R., et al. (2009). Identification of aminothienopyridazine inhibitors of tau assembly by quantitative highthroughput screening. Biochemistry, 48(32), 7732-7745. 